\title{
Heavy Metals Resides in Commercially Imported Seafood
}

Asmaa A.A. Abdelbary, Ali M. Ahmed and *Enas T. Abdelsalam

Dept. of Food Hygiene, Faculty of Veterinary Medicine, *Faculty of Science,

Suez Canal University.

\begin{abstract}
Fish is considered to be healthy food, because they have high protein and low saturated fat contents. At the same time, it may constitute a heavy metals residues above the permissible limits causing sever public health hazards to consumers. Therefore, the concentration levels of cadmium, copper, lead and zinc were determined in Saurida undosquamis, Scomber scombrus and Oreochromis niloticus samples randomly collected from Ismailia city fish markets. The mean cadmium residual levels in $S$. undosquamis, S. Scombrus and O. niloticus samples were 0.10, 0.31 and $0.52 \mathrm{mg} / \mathrm{kg}$ respectively. The mean copper residual levels in $S$. undosquamis, S. Scombrus and O. niloticus samples were 1.12, 1.61 and $0.36 \mathrm{mg} / \mathrm{kg}$ respectively. The mean lead residual levels in $S$. undosquamis, S. Scombrus and O. niloticus samples were 0.12, 0.21 and $1.22 \mathrm{mg} / \mathrm{kg}$ respectively. The mean zinc residual levels in $S$. undosquamis, S. Scombrus and O. niloticus samples were 40.30, 65.32 and $29.05 \mathrm{mg} / \mathrm{kg}$ respectively. High level of heavy metals in fish Sample which exceeded the permissible limits could produce hazard effect on human health. So it is important to protect consumer from this hazard effect of heavy metals by strict application of the following measures, the potential sources of heavy metals to the fish in the aquatic system should be identified and quantified and periodically monitoring program must be carried out to evaluate the heavy metals residual levels in fish.
\end{abstract}

\section{Introduction}

Ismailia fish markets have many fish species, whatever Saurida undosquamis, and Scomber scombrus are of the most important imported fish in the markets. These species have stood out in the market due to their characteristics such as lower prices, and higher carcass yield, besides the special characteristics of the meat, light- colored, mild flavor, and better taste. Another local production type is Oreochromis niloticus which is the common fresh type in the markets. Since food is the main source of exposure to heavy metals, and fish is a part of human food, it is not surprising that polluted fish could be a dangerous dietary source of toxic heavy metals (Bogut, 1997). The term heavy metals is applied to 
group of metals with atomic density greater than $4 \mathrm{~g} / \mathrm{cm}^{3}$ or more greater than water. Some of these metals are harmful to fish even at low levels, whereas others are biologically essential and become toxic at high concentrations. When ingested above permissible limits heavy metals join with body's biomolecules, like enzymes and proteins to form biotoxic compounds, thereby deform their structures and inhibit them from the bioreactions of their functions (Duruibe et al., 2007).

Heavy metals are of particular concern around the world because they are persistent in environment, undergo biogeo-chemical recycling, and pose ecological risks (Liu et al., 2015). Pollution of aquatic systems by heavy metals has become a worldwide problem (AbdelBaki et al., 2013). Heavy metals may enter aquatic systems from natural and human activities sources, containing industrial or domestic wastewater, application of pesticides and fertilizers, leaching from landfills, harbour and shipping activities, geological weathering of atmospheric deposition and the earth crust (Yilmaz, 2009).

The presence of heavy metals in aquatic ecosystems is a concern due to their toxicity, long persistence and their accumulative behavior (Rahman et al., 2012). Furthermore, heavy metals introducing to the aquatic ecosystem can be accumulate in fish through the effects of bioconcentration and bioaccumulation via the food chain and become toxic when accumulation reaches to high level (Huang., 2003). Heavy metals enter fish through a number of routes: via gills, skin, oral utilization of water, food and non-food particles. Once absorbed, heavy metal are transported in the circulatory system to either a storage or to the liver for transformation and storage (Obasohan, 2008). High amount of metals may accumulate in the soft and hard tissue of fish (Mansour and Sidky, 2002).

Toxic metals can be harmful even if low levels are ingested for a long time. Toxic effects can also be caused by increasing intake of essential heavy metals ( $\boldsymbol{G} \boldsymbol{u}$ et $\boldsymbol{a l}$., 2015). Consumers may subjected to heavy metals with fish tend to accumulate in the body and can be stored in tissues such as muscles, bone and liver and threaten the human health. Therefore, the heavy metals are one of the most pollutants, which received attention in multiple countries and considered one of the dangerous pollutant in the sea (Hassaan et al., 2007).

Therefore, this study was conducted to evaluate the heavy metal concentration levels in the frozen fish Saurida undosquam (Brushtooth Lizardfish), Scomber Scombrus (mackerel) and farmed fish Nile tilapia (Oreochromis niloticus.

\section{Materials and Methods}


Samples Collection: A total of 40 samples of imported frozen Scomber Scombrus (mackerel) and Brushtooth Lizardfish, Saurida undosquamis (Makrowna) were randomly collected from fish markets at Ismailia city $(n=20$ for each). Another 20 fresh samples of Nile Tilapia, Oreochromis niloticus were also randomly collected from different fish markets at Ismailia city.

All samples was identified then wrapped in plastic bag, and transferred in icebox refrigerated to Meat Hygiene Laboratory, Faculty of Veterinary Medicine, Suez Canal University for evaluation.

A marine, mainly piscivorous fish, commonly $15-35 \mathrm{~cm}$ long (max. 40 $\mathrm{cm})$. The body is brown-beige on the back with a silvery white belly, and a series of 7-10 dark spots along the lateral line. The body is slender and cylindrical; the head is slightly depressed with a large mouth and long jaws terminating behind the eye. Numerous needlelike teeth are visible when the mouth is closed. An adipose fin is present above the anal fin. First collected in the Mediterranean in Egypt (Galil, 2006), subsequently collected off Greece, Albania and Syria. Everywhere it formed thriving populations in an amazingly short space of time.

The Atlantic mackerel Scomber scombrus is distributed in North Atlantic Ocean, including the Baltic Sea, eastern Atlantic including the Mediterranean and the Black sea, also in western Atlantic from Labrador to Cape Lookout. It is an epipelagic and mesodemersal species and most abundant in cold and temperate shelf areas.

The maximum fork length is $50 \mathrm{~cm}$, but the most common length is around $30 \mathrm{~cm}$. Females become bigger than males. The most important fishing areas for $S$. scombrus are the Northwest and Northeast Atlantic, Mediterranean and Black Sea. The mackerel school is mainly caught with purse seines. The Atlantic mackerel is traded fresh, frozen, smoked and canned (Collette and Nauen, 1983).

The Nile tilapia, Oreochromis niloticus is a deep-bodied fish with cycloid scales. Silver in colour with olive/grey/black body bars, the Nile tilapia often flushes red during the breeding season (Picker and Griffiths, 2011). It grows to a maximum length of $62 \mathrm{~cm}$, weighing $3.65 \mathrm{~kg}$ (at an estimated 9 years of age). The average size (total length) of $O$. Niloticus is 20 cm (Bwanika et al., 2004). Natural distribution and habitat $O$. niloticus is native to central and North Africa and the Middle East (Boyd, 2004).

Preparation of samples: Fish were washed with deionized water and each fish was kept frozen until analysis. All plastic and glassware used were rinsed and soaked in 10\% (v/v) $\mathrm{HNO}_{3}$ over night. They were rinsed with deionized water and dried prior using (Voegborlo and Adimado, 2010). All acids (Nitric, $\mathrm{HNO}_{3} ; \quad$ Sulfuric, $\mathrm{H}_{2} \mathrm{SO}_{4}$; 
Hydrochloric, $\mathrm{HCl}$ and Perchloric acid, $\mathrm{HClO}_{4}$ ) and oxidants (Hydrogen peroxide, $\mathrm{H}_{2} \mathrm{O}_{2}$ ) were of highest quality.

Digestion of samples:

The muscular tissues on the dorsal surface of each sample was taken out and homogenized. About four grams of the homogenized muscles (without skin) of each specimen were taken and placed in a $300 \mathrm{ml}$ digestion tube.

A digestion mixture containing 6.0 $\mathrm{ml}$ of high purity $\mathrm{HNO}_{3}$ plus $2 \mathrm{ml}$ of $\mathrm{HCl}(10 \mathrm{M})$ and $4 \mathrm{ml}$ of $\mathrm{H}_{2} \mathrm{O}_{2}$ (35\%) was added to each tube. The samples were then heated at $130^{\circ} \mathrm{C}$ by kjldahl heating digester with air condenser until a clear solution was obtained. After cooling, the samples were filtered through Whatman filter paper.

The digested portion was diluted to a final volume of $50 \mathrm{ml}$ using deionized water. Blank reagents without fish samples were also digested using the same method (Manutsewee et al., 2007).

Analysis for determination levels of heavy metal residues in fish sample: Cadmium, copper, lead and zinc absorbance was recorded directly from the digital scale of Atomic Absorption
Spectrophotometer and their concentrations were calculated according to the following equation: $\mathrm{C} 1=(\mathrm{A} 1 / \mathrm{A} 2) \mathrm{C}(\mathrm{D} / \mathrm{W})$ Where $\mathrm{C} 1=$ Concentration of heavy metals $(\mu \mathrm{g} / \mathrm{g})$ wet wt.

$\mathrm{A} 1=$ Absorbance reading of the sample solution.

A2 = Absorbance reading of the standard solution.

$\mathrm{C}=$ Concentration of heavy metals $(\mu \mathrm{g} / \mathrm{ml})$ of standard solution.

$\mathrm{D}=$ Dilution of the fish samples.

$\mathrm{W}=$ Weight of muscle in each sample.

Statistical Analysis: The results were shown in tables and figures for the minimum, maximum and mean values were calculated. The Standard Error (SE) is also calculated and were subjected to one way analysis of variance (ANOVA) followed by Duncan multiple range test to assess whether the means of metal concentrations were varied significantly among fish species. Possibilities less than 0.05 were considered statistically significant $(P<0.05)$. 


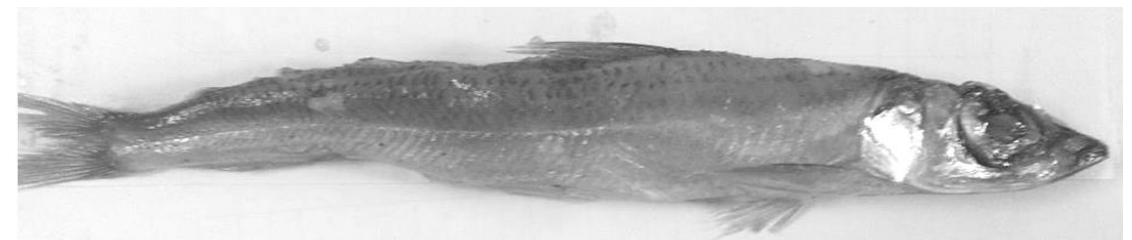

Image 1. Saurida undosquamis / Brushtooth lizard fish

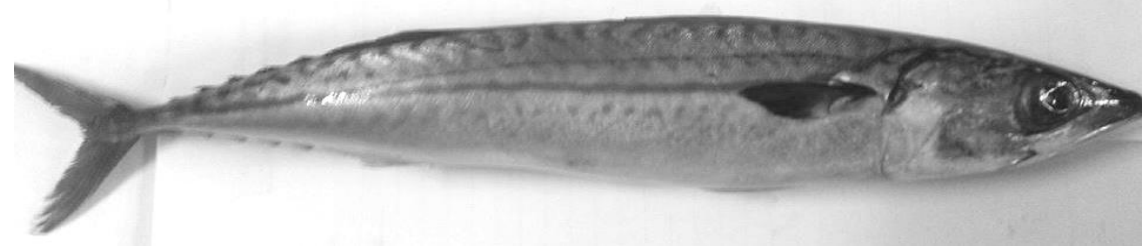

Image 2. Scomber scombrus / Atlantic mackerel

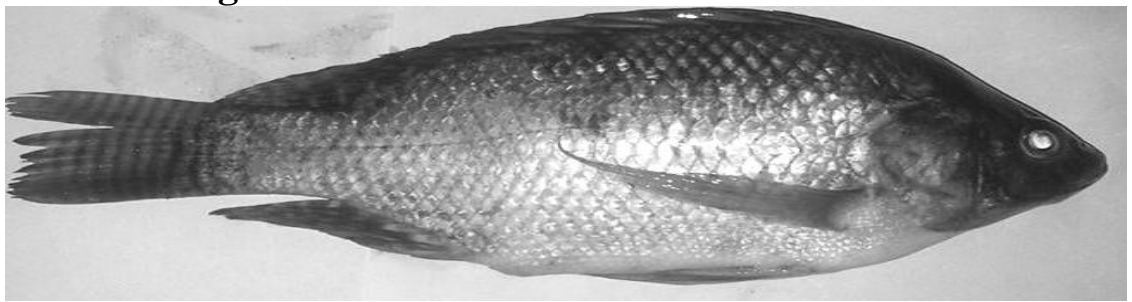

Image 3: Oreochromis niloticus, Nile Tilapia,

\section{Results and Discussion}

The human body has an elaborate system for managing and regulating the amount of key trace metals circulating in blood and stored in cells. Nutrient metals from our diet are incorporated into blood if blood levels are depleted, transported into cells if cellular levels are inadequate, or excreted if blood and cell levels are sufficient or overloaded. When this system fails to function properly, abnormal levels and ratios of trace metals can develop (Osredkar and Sustar, 2011).

\section{Cadmium Concentration Levels} in Fish: Cadmium $(\mathrm{Cd})$ is a naturally occurring metal situated in the Periodic Table of the Elements between zinc ( $\mathrm{Zn})$ and mercury $(\mathrm{Hg})$. The concentrations of cadmium in the muscle of $S$. undosquamis; S. scombrus and $O$. niloticus samples collected from different fish markets at Ismailia city are shown in Table (1). The mean cadmium residual level in $S$. undosquamis samples were $0.10 \pm$ $0.02 \mathrm{mg} / \mathrm{kg}$ (wet wt.,) with ranged between 0.001 to $0.35 \mathrm{mg} / \mathrm{kg}$ (wet wt.). For S. Scombrus samples, the mean cadmium residual level were $0.31 \pm 0.05 \mathrm{mg} / \mathrm{kg}$ (wet wt.,) with ranged between 0.01 to $0.53 \mathrm{mg} / \mathrm{kg}$ (wet wt.). For the $O$. niloticus sample, the mean cadmium residual level were $0.52 \pm 0.15 \mathrm{mg} / \mathrm{kg}$ (wet wt.) with ranged from 0.23 to 1.09 $\mathrm{mg} / \mathrm{kg}$ (wet wt.).

Regarding the geographical variation of fish samples, there were different concentrations of cadmium 
in the fish species under the study. The quantity relationships generally found for the cadmium in the muscle of fish samples were: $O$. niloticus $>S$. Scombrus $>S$. undosquamis.

An accumulation pattern of cadmium was significantly different $(P>0.05)$ between the different fish species. In the muscles, the herbivore Oreochromis niloticus accumulated the highest concentration of cadmium. It may be interperated as Oreochromis niloticus were farmed on polluted water contained higher concentrations of cadmium from different sources. Cd is mainly used in rechargeable batteries and for the production of special alloys. Although emissions in the environment have markedly declined in most industrialized countries, $\mathrm{Cd}$ remains a source of concern for industrial workers and for populations living in polluted areas, especially in less developed countries (Sethi and Khandelwal, 2006).

The International Standard for cadmium concentration levels in muscles of fish by $\boldsymbol{F A O}$ (1983) and WHO (1989) were 0.05 to 1.0 $\mathrm{mg} / \mathrm{Kg}$. All Saurida undosquamis samples are within the permissible limits for cadmium. 19 (95\%) and $16(80 \%)$ of S. Scombrus and Oreochromis niloticus samples respectively are within the permissible limits for cadmium. Out of 20 fish samples, 1 (5\%) and 4 $(20 \%)$ of S. Scombrus and
Oreochromis niloticus samples respectively are unfit for human consumption due to exceed their muscle content of cadmium than the permissible limits for cadmium. This unfit fish may constitute a public health hazards for consumers. $\mathrm{Cd}$ is efficiently retained in the human body, in which it accumulates throughout life. $\mathrm{Cd}$ is primarily toxic to the kidney, especially to the proximal tubular cells, the main site of accumulation. $\mathrm{Cd}$ can also cause bone demineralization, either through direct bone damage or indirectly as a result of renal dysfunction (Bernard, 2008).

Copper Concentration Levels in Fish: Copper appears in the periodic table at the top of Group 11 above silver and gold. Copper $(\mathrm{Cu})$ is a naturally occurring metal and essential to all living organisms. Copper is also a vital dietary nutrient, although only small amounts of the metal are needed for well-being (Araya et al., 2006). However, at the same time, it may be toxic to cell membranes, DNA and proteins when accumulated in excess (Livares and Uauy, 1996).

The concentrations levels of copper in the muscle of $S$. undosquamis; $S$. scombrus and $O$. niloticus samples collected from different fish markets at Ismailia city are shown in Table (1). The mean copper residual level in $S$. undosquamis samples were $1.12 \pm 0.31 \mathrm{mg} / \mathrm{kg}$ (wet wt.) with ranged between 0.85 to $5.01 \mathrm{mg} / \mathrm{kg}$ (wet wt.). For $S$. 
Scombrus samples, the mean copper residual level were $1.61 \pm 0.28$ $\mathrm{mg} / \mathrm{kg}$ (wet wt.) with ranged between 1.30 to $7.52 \mathrm{mg} / \mathrm{kg}$ (wet wt.). For the $O$. niloticus sample, the mean copper residual level were of $0.36 \pm 0.01 \mathrm{mg} / \mathrm{kg}$ (wet wt.) with range from 0.25 to $1.24 \mathrm{mg} / \mathrm{kg}$ (wet wt.).

Regarding the geographical variation of fish samples, there were different concentrations of copper in the fish species under the study. The quantity relationships generally found for the copper in the muscle of fish samples were: S. Scombrus > S. undosquamis $>$ O. niloticus. An accumulation pattern of copper was significantly different $\quad(P>0.05)$ between the different fish species. In the muscles, the $S$. scombrus accumulated the highest concentration of copper. Copper is introduced in to the aquatic environment through a number of natural methods as minerals in soil, extraction of copper from rock into a dissolved state, volcanic action and thermal vents (Lewis and Lewis, 1971). Copper may be released to aquatic water from different sources as plumbing pipe, heat radiators, industrial electrodes, utensils, coins, fertilizer, firework ingredient and other architectural elements (ICA, 2004).

The International Standard for copper concentration levels in muscles of fish by $\boldsymbol{F A O}$ (1983) and WHO (1989) were $30.00 \mathrm{mg} / \mathrm{Kg}$. All samples are within the permissible limits for copper so fit for human consumption. Ingesting of high concentration levels of copper with diet may cause gastrointestinal bleeding, haematuria, intravascular haemolysis, methaemoglobinaemia, hepatocellular toxicity, acute renal failure and oliguria (Agarwal et al., 1993). At lower doses, copper ions can cause symptoms typical of food poisoning as headache, nausea, vomiting, diarrhea (Stenhammar, 1999).

Lead Concentration Levels in Fish: lead is a naturally occurring element; it is a one of Group 14 (IVA) of the periodic table. Lead $(\mathrm{Pb})$ is a naturally occurring metal, it is distributed in all parts of the environment in three main forms: Metallic lead, lead salts, and organic lead containing carbon (Ahamed and Siddiqui, 2007). Lead is found in small amount in the earth crust as a result of human activities, like mining, manufacturing and the burning of fossil fuels (Castro and Huber 1997).

The concentrations of lead in the muscle of $S$. undosquamis; $S$. scombrus and $O$. niloticus samples collected from different fish markets at Ismailia city are shown in Table (1). The mean lead residual level in $S$. undosquamis samples were $0.12 \pm 0.001 \mathrm{mg} / \mathrm{kg}$ (wet wt.,) with ranged between 0.01 to 0.40 $\mathrm{mg} / \mathrm{kg}$ (wet wt.). For S. Scombrus samples, the mean lead residual level were $0.21 \pm 0.03 \mathrm{mg} / \mathrm{kg}$ (wet wt.) with ranged between 0.01to 
$0.49 \mathrm{mg} / \mathrm{kg}$ (wet wt.). For the $O$. niloticus samples, the mean lead residual levels were $1.22 \pm 0.17$ $\mathrm{mg} / \mathrm{kg}$ (wet wt.,) with ranged between 0.31 to $1.49 \mathrm{mg} / \mathrm{kg}$ (wet wt.). Regarding the geographical variation of fish samples, there were different concentrations of lead in the fish species under the study. The quantity relationships generally found for the lead in the muscle of fish samples were: $O$. niloticus $>S$. Scombrus > S. undosquamis. An accumulation pattern of lead was significantly different $(P>0.05)$ between Oreochromis niloticus and other fish species under study.

In the muscles, the Oreochromis niloticus accumulated the highest concentration of lead. It may be interpreted as Oreochromis niloticus were farmed on polluted water contain higher concentrations of lead from different sources. Lead is considered as one of the most hazards and cumulative environmental pollutants that affect all biological systems through exposure to air, water, and food sources (Patra et al., 2011). The exposure to lead induces pathological changes through toxicity occurring in kidney and endocrine system (Jadhav et al., 2007).

The International Standard for lead concentration levels in muscles of fish by $\mathrm{FAO}$ (1983) and $\mathrm{WHO}$ (1989) were 0.50 to $2.0 \mathrm{mg} / \mathrm{Kg}$. All $S$. undosquamis and S. Scombrus samples are within the permissible limits for lead. 15 (75\%) of
Oreochromis niloticus samples are within the permissible limits for lead.

Zinc Concentration Levels in

Fish: Zinc $(\mathrm{Zn})$ is a bluish white soft metal, belongs to group II-B of the periodic table, it has atom weight of 65.38 , and density of 7.13 (Bradi, 2005). The concentrations of zinc in the muscle of $S$. undosquamis; S. scombrus and $O$. niloticus samples collected from different fish markets at Ismailia city are shown in Table (1). The mean zinc residual level in $S$. undosquamis samples were $40.30 \pm$ $8.10 \mathrm{mg} / \mathrm{kg}$ (wet wt.) with ranged between 22.36 to $50.30 \mathrm{mg} / \mathrm{kg}$ (wet wt.). For S. Scombrus samples, the mean zinc residual level were 65.32 $\pm 12.30 \mathrm{mg} / \mathrm{kg}$ (wet wt.) with ranged between 46.22 to 70.63 $\mathrm{mg} / \mathrm{kg}$ (wet wt.). For the $O$. niloticus sample, the mean zinc residual levels were $29.05 \pm 10.50$ $\mathrm{mg} / \mathrm{kg}$ (wet wt.) with ranged from 18.35 to $30.21 \mathrm{mg} / \mathrm{kg}$ (wet wt.).

Regarding the geographical variation of fish samples, there were different concentrations of zinc in the fish species under the study. The quantity relationships generally found for the zinc in the muscle of fish samples were: $S$. Scombrus $>S$. undosquamis $>O$. niloticus. An accumulation pattern of zinc was significantly different $(P>0.05)$ between the different fish species. In the muscles, the $S$. Scombrus accumulated the highest concentration of zinc. It may be interperated as $S$. Scombrus 
environment contained higher concentrations of zinc from different sources.

The main sources of $\mathrm{Zn}$ pollution in the environment are zinc fertilizers, sewage sludges, and mining (Bradi, 2005). Zinc is an essential element for the life of animal and human beings. It present in many enzymes involved in important physiological functions like protein synthesis. Also it is essential for male reproductive activity (Momtaz, 2002). The International Standard for zinc concentration levels in muscles of fish by $\boldsymbol{F A O}$ (1983) and WHO (1989) were 30 to $100 \mathrm{mg} / \mathrm{Kg}$. All fish samples are within the permissible limits for zinc. Zn excess amount can cause system dysfunctions, impairment of growth and reproduction, The clinical signs of $\mathrm{Zn}$ toxicosis have been reported as vomiting, diarrhea, bloody urine, icterus (yellow mucus membrane), liver failure, kidney failure and anemia (Duruibe et al., 2007).

The findings of this study concluded that Heavy metals residues were detected in all fish samples under the study by different values. Copper and zinc concentration levels were within the International slandered Limits in all fish samples collected from Ismailia city markets. The study confirmed the potential health risks from Tilapia fish due to their residual levels of cadmium and lead which exceed the international slandered limits.

Table 1. Cadmium, copper, lead and zinc concentration levels ( $\mathrm{mg} / \mathrm{kg}$ wet wt) in fish samples

\begin{tabular}{|c|c|c|c|c|c|c|c|c|c|}
\hline $\begin{array}{c}\text { Fish } \\
\text { samples }\end{array}$ & \multicolumn{3}{|c|}{ S. undosquamis } & \multicolumn{3}{c|}{ S. scombrus } & \multicolumn{3}{c|}{ O. niloticus } \\
\hline parameters & min & max & $\begin{array}{c}\text { Mean } \\
\pm \text { SE }\end{array}$ & min & max & $\begin{array}{c}\text { Mean } \\
\pm \text { SE }\end{array}$ & min & max & $\begin{array}{c}\text { Mean } \\
\pm S E\end{array}$ \\
\hline Cadmium & 0.001 & 0.35 & 0.10 & 0.01 & 0.53 & 0.31 & 0.23 & 1.09 & 0.52 \\
\pm 0.02 & & & \pm 0.05 & & & \pm 0.15 \\
\hline Copper & 0.85 & 5.01 & 1.12 & 1.30 & 7.52 & 1.61 & 0.25 & 1.24 & 0.36 \\
\pm 0.31 & & & \pm 0.28 & & & \pm 0.01 \\
\hline Lead & 0.01 & 0.40 & 0.12 & 0.01 & 0.49 & 0.21 & 0.31 & 1.49 & 1.22 \\
\pm 0.001 & & & \pm 0.03 & & & \pm 0.17 \\
\hline Zinc & 22.36 & 50.30 & 40.30 & 46.22 & 70.63 & $\begin{array}{c}65.32 \\
\pm 12.30\end{array}$ & 18.35 & 30.21 & $\begin{array}{c}29.05 \\
\pm 10.50\end{array}$ \\
& & & & & \pm 12.30 & & & \pm 10.50 \\
\hline
\end{tabular}

Min : Minimum value

Max : Maximum value

SE $\quad: \pm$ Standard Error 
Table 2. Frequency distribution of concentration levels of cadmium, copper, lead and zinc in the fish compared to International standards

\begin{tabular}{|c|c|c|c|c|c|c|c|c|c|c|c|c|}
\hline Fish samples & \multicolumn{4}{|c|}{$\begin{array}{l}\text { S. undosquamis } \\
\text { No. }(\%)\end{array}$} & \multicolumn{4}{|c|}{$\begin{array}{l}\text { S. scombrus } \\
\text { No. }(\%)\end{array}$} & \multicolumn{4}{|c|}{$\begin{array}{l}\text { O. niloticus } \\
\text { No. }(\%)\end{array}$} \\
\hline parameters & Cd & $\mathrm{Cu}$ & $\mathbf{P b}$ & $\mathbf{Z n}$ & Cd & $\mathrm{Cu}$ & $\mathbf{P b}$ & $\mathbf{Z n}$ & Cd & $\mathrm{Cu}$ & $\mathbf{P b}$ & Zn \\
\hline $\begin{array}{l}\text { Within the } \\
\text { International } \\
\text { Standard }\end{array}$ & $\begin{array}{c}20 \\
100(\%)\end{array}$ & $\begin{array}{c}20 \\
100(\%)\end{array}$ & $\begin{array}{c}20 \\
100(\%)\end{array}$ & $\begin{array}{c}20 \\
100(\%)\end{array}$ & $\begin{array}{c}19 \\
95(\%)\end{array}$ & $\begin{array}{c}20 \\
100(\%)\end{array}$ & $\begin{array}{c}20 \\
100(\%)\end{array}$ & $\begin{array}{c}20 \\
100(\%)\end{array}$ & $\begin{array}{c}16 \\
80(\%)\end{array}$ & $\begin{array}{c}20 \\
100(\%)\end{array}$ & $\begin{array}{c}15 \\
75(\%)\end{array}$ & $\begin{array}{c}20 \\
100(\%)\end{array}$ \\
\hline $\begin{array}{l}\text { Exceed the } \\
\text { International } \\
\text { Standard }\end{array}$ & $\begin{array}{c}0 \\
0.00(\%)\end{array}$ & $\begin{array}{c}0 \\
0.00(\%)\end{array}$ & $\begin{array}{c}0 \\
0.00(\%)\end{array}$ & $\begin{array}{c}0 \\
0.00(\%)\end{array}$ & $\begin{array}{c}1 \\
5(\%)\end{array}$ & $\begin{array}{c}0 \\
0.00(\%)\end{array}$ & $\begin{array}{c}0 \\
0.00(\%)\end{array}$ & $\begin{array}{c}0 \\
0.00(\%)\end{array}$ & $\underset{20(\%)}{4}$ & $\begin{array}{c}0 \\
0.00(\%)\end{array}$ & $\begin{array}{c}5 \\
25(\%)\end{array}$ & $\begin{array}{c}0 \\
0.00(\%)\end{array}$ \\
\hline
\end{tabular}

International Standard according to FAO, (1983) and WHO, (1989).

\section{References}

Abdel-Baki, A., Dkhil, M., and Al-Quraishy, S. (2013): Bioaccumulation of some heavy metals in tilapia fish relevant to their concentration in water and sediment of Wadi Hanifah, Saudi Arabia. African J. of Bio., 10, 13: 2541-2547. Retrieved from http://www.ajol.info/index.php/ajb/ article/view/ 93185.

Agarwal, S.K.; Tiwari, S.C., and Dash, S.C., (1993): Spectrum of poisoning requiring hemodialysis in a tertiary care hospital in India. International Journal of Artificial Organs, 16, 1: 20-22.

Ahamed, M. and Siddiqui, M.K. J. (2007): Environmental lead toxicity and nutritional factors. Clin. Nutr., 26, 4: 400-408.

Araya M., Pizarro F., Olivares M., Arredondo M., Gonzalez M., (2006): Understanding copper homeostasis in humans and copper effects on health. Biol Res., 39: 183-187.
Bernard, A. (2008): Cadmium and its adverse effects on human health. Indian J. Med. Res., 128: 557-564.

Bogut, I. (1997): Water pollution by heavy metals and their impact on fish and human health. Hrvatske Vode., 5: 223-229.

Boyd, E.C. (2004): Farm-Level Issues in Aquaculture Certification: Tilapia. Report commissioned by WWFUS . Auburn University, Alabama 36831.

Bradi, B.H., (2005): Heavy metals in the environment. Interface Science and Technology, Hubbard, A., (ed.), 6, Elsevier Academic Press: Neubrucke 74-Momtaz, M., Geochemical studies of Heavy Metals in the Seawater along Karachi Makran Coast, University of Karachi: Karachi., pp. 414.

Bwanika, G.N., Makanga, B., Kizito, Y., Chapman, L.J. and Balirwa, J. (2004): Observations on the biology of Nile tilapia, Oreochromis niloticus, L., in two Ugandan Crater lakes. African Journal of Ecology 42: 93-101. 
Castro, P. and Huber M., (1997): Marine Biology. $2^{\text {nd }}, \quad$ WCB/Mc Graw Hill.

Collette, B.B. and Nauen, C.E. (1983): FAO species catalogue. Vol. 2. Scombrids of the world. An annotated and illustrated catalogue of tunas, mackerels, bonitos and related species known to date. FAO Fisheries Synopsis No. 125, Vol. 2: Food and Agriculture Organization of the United Nations. Rome, Italy. $137 \mathrm{p}$.

Duruibe, J.O., Ogwuegbu, M.C. and Egwurugwu, J.N. (2007): Heavy metal pollution and human biotoxic effects. International Journal of Physical Sciences, 2: $112-118$.

FAO (1983): Compilation of legal limits for hazardous substances in fish and fishery products. FAO Fishery Circular No. 464, Food and Agriculture Organization, pp. 5-100. Galil, B.S., (2006): The marine caravan - the Suez Canal and the Erythrean invasion. In: Gollasch, S., Galil, B.S., Cohen, A.N. (Eds.), Bridging Divides: Maritime Canals as Invasion Corridors. Monographiae Biologicae 83. Springer, pp. 207-300.

Gu, Y.G., Lin, Q., Wang, X.H., Du, F.Y., Yu, Z.L. and Huang, H.H., (2015): Heavy metal concentrations in wild fishes captured from the South China Sea and associated health risks. Mar. Pollut. Bull. 96, 508-512.

Hassaan M.H., Al-Kahali, M. and Al-Edres, M. (2007): Heavy Metal Contamination in the White
Muscles of Some Commercial Fish Species From Al-Hodeidah-Red Sea coast of Yemen.[cited; Available from:

http://ipac.kacst.edu.sa/eDoc/2007/1 65228_2.pdf.

Huang, B.W. (2003): Heavy metal concentrations in the common benthic fishes caught from the coastal waters of Eastern Taiwan. Journal of food and drug analysis, 11, 4: 324-330.

ICA, International Copper Association (2004): "Copper Products" information on the ICA Internet site www.copperinfo.com. Jadhav, S.H., Sarkar, S.N., Patil, R.D. and Tripathi, H.C. (2007): Effects of subchronic exposure via drinking water to a mixture of eight water contaminating metals: A biochemical and histopathological study in male rats. Arch. Environ. Con. Toxicol., 53(4): 667-677.

Lewis, S.D., and Lewis W. M., (1971): The effect of zinc and copper on the osmolality blood serum of the channel catfish (Ictalarius punctatus) Rafinesque, and golden shiner (Notemigonus Crysoleucas) Mitchell. Transactions of the American fisheries society. 100: 639-643.

Liu, J.L., Xu, X.R., Ding, Z.H., Peng, J.X., Jin, M.H., Wang, Y.S., Hong, Y.G. and Yue, W.Z., (2015): Heavy metals in wild marine fish from South China Sea: levels, tissue-and species-specific accumulation and potential risk to humans Ecotoxicology, 1-10. 
Livares, M. and Uauy, R. (1996): Copper as an essential element. Am. J. Clin. Nutr., 63: 791-796.

Mansour, S.A. and Sidky, M.M. (2002): Heavy

metals contaminating water and fish from Fayoum Governorate, Egypt. Food Chememistry, 78: 15-22.

Manutsewee, N., Aeungmaitrepirom, W. Varanusupakul, P. and Imyim, A.(2007) Determination of $\mathrm{Cd}, \mathrm{Cu}$, and $\mathrm{Zn}$ in fish and mussel by AAS after ultrasoundassisted acid leaching extraction. Food Chemistry, 2007. 101: p. 817.824

Momtaz, M. (2002): Geochemical studies of Heavy Metals in the Seawater along Karachi Makran Coast. University of Karachi, Karachi. p. 414.

Obasohan, E. E. (2008): Bioaccumulation of chromium, copper, maganese, nickel and lead in a freshwater cichlid, hemichromis fasciatus from Ogba River in Benin City, Nigeria. African Journal of General Agriculture, 4(3): p. 141-152.

Osredkar, J. and Sustar, N. (2011): Copper and Zinc, Biological Role and Significance of Copper/Zinc Imbalance. J. Clinic. Toxicol., S, 3: 1-18.

Patra, R.C., Rautray, A.K. and Swarup, D. (2011): Oxidative stress in lead and cadmium toxicity and its amelioration. J. Vet. Intern. Med., 457327.

Picker, M.D. and Griffiths, C.L. (2011): Alien and Invasive Animals - A South African Perspective.
Randomhouse/Struik Cape Town. 240pp.

Rahman, M. S., Molla, A. H., Saha, N., and Rahman, A. (2012): Study on heavy metals levels and its risk assessment in some edible fishes from Bangshi River, Savar, Dhaka, Bangladesh. Food Chemistry, 134(4), 1847-54.

Sethi, P.K. and Khandelwal, D.J. (2006): Cadmium exposure: health hazards of silver cottage industry in developing countries. Med Toxicol.; 2: 14-15.

Stenhammar, L. (1999): Diarrhoea following contamination of drinking water with copper. European Journal of Medical Research, 4: 217-218.

Voegborlo, R.B. and Adimado, A.A. (2010): A simple classical wet digestion technique for the determination of total mercury in fish tissue by cold-vapour atomic absorption spectrometry in a low technology environment. Food Chemistry. 123(3): p. 936-940.

WHO

(World

Health Organization) (1989): Heavy metals -environmental aspects. Environment health criteria. No. 85. Geneva, Switzerland.

Yilmaz, F.(2009):The Comparison of Heavy Metal Concentrations $(\mathrm{Cd}$, $\mathrm{Cu}, \mathrm{Mn}, \mathrm{Pb}$, and $\mathrm{Zn}$ ) in Tissues of Three Economically Important Fish (Anguilla anguilla, Mugil cephalus and Oreochromis niloticus) Inhabiting Köycegiz Lake- Mugla (Turkey). Turkish Journal of Science \& Technology. 4(1): p. 715. 


$$
\begin{aligned}
& \text { متبقيات بعض العناصر الثقيلة في المأكولات البحرية المستوردة }
\end{aligned}
$$

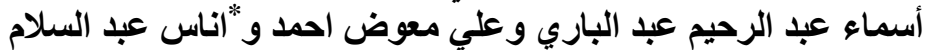

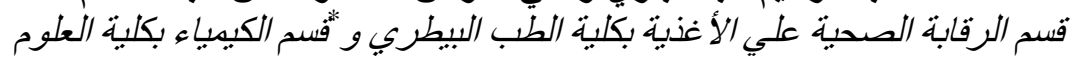

$$
\begin{aligned}
& \text { جامعة قناة السوبيس - الإسعاعيلية }
\end{aligned}
$$

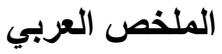

تعتبر الأسماك من الأغذية الصحية للإنسان لاحتوائها علي نسبه عاليه من البروتين عالي القيمة

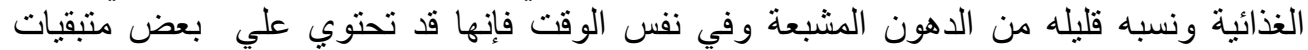

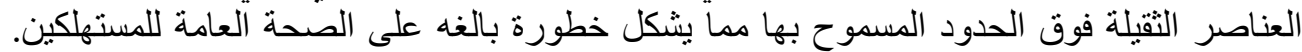

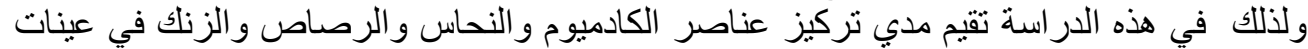

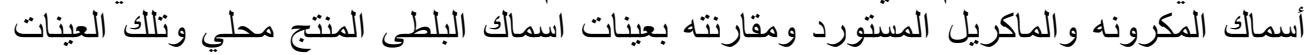

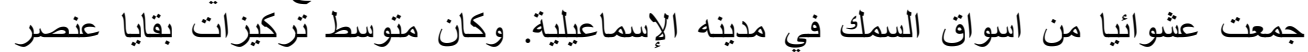
الكادميوم في عينات أسماك المكرونه و الماكريل والبلطي هو هو

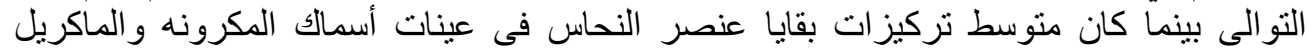

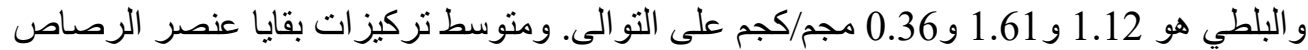

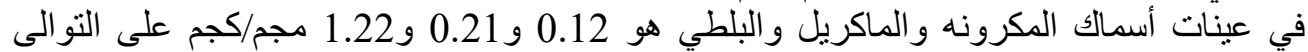
وكان متوسط تركيزات بقايا عنصر الزنك في عينات المكرونه و والماكريل و البلطي هو

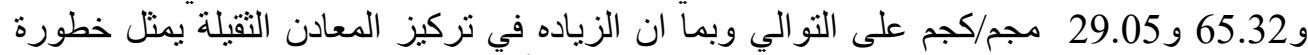

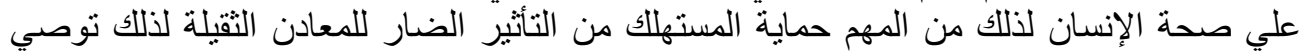

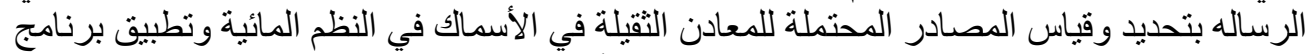

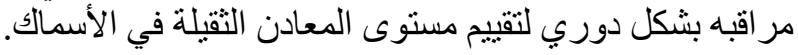

